\title{
Effect of Amidated Low-Methoxyl Pectin on Physicochemical Characteristics of Jumbo Squid (Dosidicus gigas) Mantle Muscle Gels
}

\author{
Juan C. Ramirez-Suarez ${ }^{1 *}$ Andrés Álvarez-Armenta ${ }^{1}$, Guillermina García-Sánchez ${ }^{1}$, \\ Ramón Pacheco-Aguilar ${ }^{1}$, Susana M. Scheuren-Acevedo ${ }^{1}$, Miguel A. Mazorra-Manzano ${ }^{2}$ \\ and Agustín Rascón-Chu \\ ${ }^{1}$ Fishery Products Quality Laboratory, Food and Development Research Center, \\ A.C. Carretera a La Victoria Km. 0.6, MX-83304 Hermosillo, Sonora, Mexico \\ ${ }^{2}$ Dairy Products Laboratory, Food and Development Research Center, \\ A.C. Carretera a La Victoria Km. 0.6, MX-83304 Hermosillo, Sonora, Mexico \\ ${ }^{3}$ Plants and Fungi Biotechnology Laboratory, Food and Development Research Center, \\ A.C. Carretera a La Victoria Km. 0.6, MX-83304 Hermosillo, Sonora, Mexico \\ Received: September 29, 2016 \\ Accepted: May 23. 2017
}

\begin{abstract}
Summary
Jumbo squid (Dosidicus gigas) muscle proteins show low functionality with limited use in gel products. This work aims to assess the influence of adding the natural and commercially available fibre, amidated low-methoxyl pectin (at 0.5, 1.0, 1.5, 2.0 and $3.0 \%$ ), on the physicochemical and functional characteristics of jumbo squid (Dosidicus gigas) mantle muscle gels. The addition of $0.5 \%$ fibre showed an immediate effect on the gel texture profile analysis, improving hardness $(\mathrm{p}<0.05)$ from $(3.4 \pm 0.7) \mathrm{N}$ of the control (no added fibre) to $(5.2 \pm 0.9) \mathrm{N}$, and increasing elasticity $(\mathrm{p} \geq 0.05)$. Shear force was significant only at $3.0 \%$ fibre addition. Water holding capacity also improved $(\mathrm{p}<0.05)$ with fibre addition (from 75 $\%$ in the control to $90-95 \%$ after the treatments). Whiteness was affected $(p<0.05)$ when 3.0 $\%$ fibre was added. Differential scanning calorimetry showed two endothermic transition peaks in the gels. The second peak (actin) increased $(\mathrm{p}<0.05)$ by $1-2{ }^{\circ} \mathrm{C}$ with fibre addition. Therefore, the present study demonstrates that amidated low-methoxyl pectin (0.5-3.0\%) is an excellent ingredient to improve jumbo squid mantle muscle protein functionality, increasing the gel texture and water retention characteristics.
\end{abstract}

Key words: jumbo squid, amidated low-methoxyl pectin, gelling, water retention

\section{Introduction}

Jumbo squid (Dosidicus gigas) is a cephalopod that plays a valuable role in the pelagic ecosystem of the Gulf of California (1). Most of its capture is exported to Asian and European countries, either fresh-frozen or cooked- -salted (daruma), with almost no added value. Its commercial attractiveness lies in its low cost, high processing yield (up to $75 \%$ after gutting), low fat, and muscle whiteness. Several efforts have been attempted to use its muscle as a raw material for various gel-type products (2-4). Nevertheless, its muscle forms weak gels with low water

*Corresponding author: Phone: +52 6622892400 ext. 368; Fax: +52 662280 0421; E-mail: jcramirez@ciad.mx

ORCID IDs: 0000-0001-8512-1271 (Ramirez-Suarez), 0000-0001-8907-947X (Álvarez-Armenta), 0000-0003-3748-0530 (García-Sánchez), 0000-0002-1669-8007 (Pacheco-Aguilar), 0000-0001-5801-4593 (Scheuren-Acevedo), 0000-0002-1425-4250 (Mazorra-Manzano), 0000-0003-2759-0525 (Rascón-Chu) 
holding capacity (WHC) (5,6). Thus, there is a need to find a gel-improving additive if this muscle is going to be used as a raw material for these products.

Various types of fibre, such as glucomannan, wheat and oat fibre, cellulose, carrageenan, and pea fibre, have been studied to improve the gelling and WHC characteristics of a range of fish and beef muscles, modifying the functional, as well as technological properties of the final product (7-9). When added to gel formulations (sometimes used as a fat replacer), the fibre has a profound effect on the physicochemical interactions and structural changes of the protein system (10), generating an improved product, without affecting its edible quality (8). Furthermore, fibre consumption has been associated with a reduction in the risk of coronary heart disease, stroke, hypertension, diabetes, obesity development, and some gastrointestinal diseases (11).

Pectin is abundantly found in vegetable tissues and commonly used as a food ingredient for several applications (12). It is a complex polysaccharide consisting mainly of esterified $\alpha$-(1 $\rightarrow 4)$-D-galacturonic acid units. Some of the carboxyl groups are partially esterified by methoxy groups $\left(-\mathrm{OCH}_{3}\right)$ at the $\mathrm{C} 6$ position and/or acetyl groups $\left(-\mathrm{O}-\mathrm{C}(\mathrm{O}) \mathrm{CH}_{3}\right)$ at the $\mathrm{O} 2$ and/or $\mathrm{O} 3$ positions, depending on the plant species (13). Additionally, its carboxylic groups can be amidated by a relatively simple chemical modification, obtaining amidated low-methoxyl pectin (ALMP), a compound that imparts certain functionality to gel products. Although pectin and its derivatives are used abundantly in the food industry, no reports have been made on their use to improve jumbo squid muscle gelation. Hence, the main objective of the present research is to assess the addition of ALMP, as a commercial natural fibre, added at $0.5,1.0,1.5,2.0$ and $3.0 \%$, on the physicochemical and functional characteristics of jumbo squid (D. gigas) mantle muscle gels.

\section{Materials and Methods}

\section{Sample}

The raw mantle muscle of jumbo squid (Dosidicus gigas) was obtained in a frozen state from a local fishery located in Hermosillo, Sonora, Mexico, in the summer of 2013. The specimens were captured in the Gulf of California. The mantles were thawed at $2-4{ }^{\circ} \mathrm{C}$ overnight, cleaned from the internal and external collagenous tunics, and finally cut into $2 \mathrm{~cm} \times 2 \mathrm{~cm}$ sections. The samples were kept at $2-4{ }^{\circ} \mathrm{C}$ before analysis.

\section{Proximate analysis}

Compositional properties of the gels were determined according to the Association of Official Analytical Chemists (AOAC) standards for water (method 950.46) (14), crude protein (method 984.13) (15), using 6.25 as the conversion factor, lipid (method 960.39) (16), and ash (method 938.08) (17) contents.

\section{Gel preparation}

Sols were prepared by combining $4.0 \mathrm{~g}$ of $\mathrm{NaCl}$ with $196 \mathrm{~g}$ of muscle using a Cuisinart DLC-8 food processor (Cuisinart Inc., Greenwich, CT, USA) applied with three bursts of 30-second intervals until the temperature reached $5{ }^{\circ} \mathrm{C}$. Then, the final moisture of the sol-gels was adjusted to $80 \%$ with sucrose, as described by Cortés-Ruiz et al. (18). GRINDSTED ${ }^{\circledR}$ LA 410 commercial citrus pectin (ALMP; Danisco USA Inc., New Century, KS, USA) with $29-33 \%$ degree of esterification and 17-21 \% degree of amidation) was added to the sol-gels at 0.5, 1.0, 1.5, 2.0 and $3.0 \%$. The sol-gels were vacuum packed in polyethylene bags that were then placed in stainless steel tubes (3.5 $\mathrm{cm}$ i.d. $\times 7.5 \mathrm{~cm}$ length) and heated in a water bath at $90{ }^{\circ} \mathrm{C}$ for $30 \mathrm{~min}$ to form gels. After that, the tubes were immediately immersed in an ice-water bath and held overnight at $2-4{ }^{\circ} \mathrm{C}$ before analysis.

\section{Gel-forming ability}

The gel-forming ability of samples was evaluated by texture profile analysis (TPA), Warner-Bratzler shear force (WBSF) and the folding test. TPA was conducted on cylindrical samples of uniform dimensions $(1 \mathrm{~cm}$ diameter $\times 1$ $\mathrm{cm}$ height) obtained from each gel using a sharp-edged plastic tube sampler. Gels were left at ambient temperature $\left(25^{\circ} \mathrm{C}\right)$ for $30 \mathrm{~min}$ before analysis. Texture was analysed using a Texture Lab Pro texturometer (Food Technology Corp., Sterling, VA, USA) using a $2.5-\mathrm{cm}$ diameter compression plunger attached to a $10 \mathrm{~N}$ load cell. The samples were compressed twice to $75 \%$ of the original gel sample height at a speed of $1 \mathrm{~mm} / \mathrm{s}$ to obtain the gel hardness, springiness and cohesiveness according to Bourne (19).

As described by Zhang and Mittal (20), the WBSF was analysed on tempered (as per the TPA analysis) rectangular gels $(1 \mathrm{~cm}$ height $\times 1 \mathrm{~cm}$ width $\times 3 \mathrm{~cm}$ length) using a Warner-Bratzler blade attached to a texturometer (Food Technology Corp.) with a $10 \mathrm{~N}$ load cell and operating at a speed of $2 \mathrm{~mm} / \mathrm{s}$ at $30 \mathrm{~mm}$ displacement. The maximum force (highest peak) resulting from the analysis was recorded as the shear force.

The folding test involved folding the gel slices (3.0 $\mathrm{mm}$ thickness $\times 30.0 \mathrm{~mm}$ diameter) between the thumb and index finger, as described previously (21). The gel samples were graded according to their cracking degree during folding, as follows: grade AA=extremely elastic (no cracks on folding into quarters), grade $A=$ moderately elastic (no cracks on folding in half, but cracks on folding into quarters), grade $\mathrm{B}=$ slightly elastic (some cracks on folding in half), grade $C=$ non-elastic (breaks into pieces on folding in half), and grade $\mathrm{D}=$ poor (breaks into pieces with finger pressure). Five slices per gel per replicate were analysed.

\section{Water holding capacity}

The water holding capacity (WHC) was evaluated using the technique outlined by Jiang et al. (22), whereby $5 \mathrm{~g}$ of each gel were centrifuged at $3000 \times g$ for $20 \mathrm{~min}$ at $4{ }^{\circ} \mathrm{C}$ (Beckman J2-21 centrifuge; Beckman Instrument Inc., Palo Alto, CA, USA). WHC was expressed as the percentage of retained water relative to the amount of water present in the sample before centrifugation.

\section{Tristimulus colourimetry of gels}

A Konica-Minolta CR-400 Tristimulus colourimeter (Konica Minolta Sensing, Inc., Tokyo, Japan) was used to objectively measure CIE $L^{*}$ (brightness), $a^{*}$ (redness/ 
greenness) and $b^{*}$ (yellowness/blueness) parameters of the cast gels, as mentioned by Lanier (23). Data were obtained from six different measurement sites on the gel. Whiteness index (WI) was calculated from the $L^{*}, a^{*}$ and $b^{*}$ values using the following equation:

$$
\mathrm{WI}=100-\left[\left(100-L^{*}\right)^{2}+\left(a^{*}\right)^{2}+\left(b^{*}\right)^{2}\right]^{1 / 2}
$$

\section{Differential scanning calorimetry}

Changes in protein thermal stability of sol-gels with added fibre $(2.5 \% \mathrm{NaCl}$ and $80 \%$ moisture) were measured using a DSC7 Perkin Elmer calorimeter (Perkin Elmer de México S.A., Monterrey, México). Approximately $50 \mathrm{mg}$ of sample were loaded into the stainless steel pan and sealed hermetically. An empty pan was used as a reference. A calibration for temperature accuracy using indium was conducted. Samples were heated from 20 to $90{ }^{\circ} \mathrm{C}$ at a constant rate of $5{ }^{\circ} \mathrm{C} / \mathrm{min}$. Thermograms were analysed with the Pyris ${ }^{\mathrm{TM}}$ v. 4.02 software (24) to obtain the onset temperature $\left(t_{\text {onset }}\right)$, the temperature at maximum heat flow $\left(t_{\max }\right)$, and heat enthalpy $(\Delta H)$.

\section{Sodium dodecyl sulphate-polyacrylamide gel electrophoresis}

The potential effect of added fibre on protein interactions during heat-induced gel network formation was evaluated by SDS-PAGE, performed according to Laemmli (25) with some modifications (26). Aliquots of $2 \mathrm{~g}$ (gel) were blended with $18 \mathrm{~mL}$ of dissolved solution (5\% SDS, $0.1 \% \beta$-mercaptoethanol) using an Ultra-Turrax ${ }^{\circledR} \mathrm{T}$ 25 D S1 homogeniser (IKA Works Inc., Wilmington, NC, USA). Fresh mantle muscle was also treated with the dissolved solution. The homogenates were incubated at 80 ${ }^{\circ} \mathrm{C}$ per $1 \mathrm{~h}$ for maximal solubilisation and protein extraction, and centrifuged at 3000×g (Beckman J2-21 centrifuge) for $15 \mathrm{~min}$. The protein amount of the supernatants was measured by the biuret method. The samples $(0.2 \%$ protein) were then mixed (at a 1:1 volume ratio) with SDS-PAGE sample buffer (4\% SDS, $20 \%$ glycerol, $10 \%$ $\beta$-mercaptoethanol and 0.125 $\mathrm{M}$ Tris, $\mathrm{pH}=6.8$ ) and dissolved by heating in boiling water for $3 \mathrm{~min}$. Aliquots of $30 \mu \mathrm{g}$ of protein per well were loaded onto an acrylamide gel (10\% resolving, $4 \%$ stacking) with dimensions of 80 $\mathrm{mm} \times 60 \mathrm{~mm} \times 1.5 \mathrm{~mm}$ (width $\times$ height $\times$ thickness). For protein markers, a broad-range molecular mass protein standard (Bio-Rad Laboratories, Richmond, CA, USA) was used. After electrophoresis, the gel was stained with
$0.125 \%$ (mass per volume) Coomassie Brilliant Blue R-250 (Bio-Rad Laboratories) in $40 \%$ (by volume) methanol and $7 \%$ (by volume) acetic acid, and destained with $50 \%$ (by volume) methanol and $10 \%$ (by volume) acetic acid. Methanol and acetic acid were purchased from Sigma-Aldrich Inc. (St. Louis, MO, USA).

\section{Experimental design}

Data were analysed by one-way analysis of variance using NCSS 97 statistical software (27). When differences among mean values were found at $5 \%$ significance level, a Tukey-Kramer mean comparison was conducted. All analyses were conducted in triplicate for each sampling $(N=3)$.

\section{Results and Discussion}

\section{Raw matter characterisation}

Although jumbo squid muscle composition has been extensively studied by several authors $(6,18,28)$, its characterisation is important to proceed with the sol-gel formation process. The species had a similar composition to previous reports $(6,18,28)$, with $(85.3 \pm 1.0) \%$ water, $(12.7 \pm$ $0.6) \%$ protein, $(1.1 \pm 0.1) \%$ lipid and $(2.4 \pm 0.1) \%$ ash content.

\section{Effect of ALMP on gel forming ability of muscle}

Protein gelation involves interactions of protein molecules under controlled conditions to form a three-dimensional network, which can entrap water. This particular system can be improved, when needed, by adding various types of compounds, such as ALMP. Table 1 shows the effect of ALMP addition on the TPA of jumbo squid muscle gels. In general, fibre addition improved the gel texture, increasing $(\mathrm{p}<0.05)$ hardness, cohesiveness and springiness values. Particularly, $0.5 \%$ fibre showed a statistically significant effect $(\mathrm{p}<0.05)$ on gel hardness compared to the control. The hardness values of samples with intermediate fibre content (1.0-2.0\%) were higher than the control $(\mathrm{p}<0.05)$ but lower than $0.5 \%$ fibre addition. However, 1.5 and $2.0 \%$ treatments were not significantly different $(p \geq 0.05)$. Samples with the highest fibre mass fraction $(3.0 \%)$ also had the highest hardness $(p<0.05)$ value. Further analysis must be conducted to elucidate which gel hardness data have corresponding sensorial attractiveness.

Table 1. Gel-forming ability of jumbo squid mantle muscle gels formulated with various mass fractions of amidated low-methoxyl pectin (ALMP)

\begin{tabular}{|c|c|c|c|c|c|}
\hline$w(\mathrm{ALMP}) / \%$ & Hardness/N & Cohesiveness & Springiness/\% & Shear force/N & Folding test \\
\hline 0.0 & $(3.4 \pm 0.7)^{\mathrm{a}}$ & $(0.28 \pm 0.1)^{b}$ & $(0.80 \pm 0.1)^{\mathrm{ab}}$ & $(5.9 \pm 1.9)^{\mathrm{ab}}$ & $\mathrm{B}-\mathrm{C}$ \\
\hline 0.5 & $(5.2 \pm 0.9)^{c}$ & $(0.31 \pm 0.1)^{\mathrm{ab}}$ & $(0.85 \pm 0.1)^{\mathrm{b}}$ & $(4.6 \pm 1.5)^{\mathrm{a}}$ & $A-B$ \\
\hline 1.0 & $(4.4 \pm 0.8)^{\mathrm{b}}$ & $(0.29 \pm 0.1)^{\mathrm{ab}}$ & $(0.82 \pm 0.1)^{\mathrm{ab}}$ & $(5.6 \pm 1.8)^{\mathrm{ab}}$ & A-B \\
\hline 1.5 & $(4.7 \pm 1.3)^{\mathrm{bc}}$ & $(0.28 \pm 0.1)^{\mathrm{b}}$ & $(0.80 \pm 0.1)^{\mathrm{ab}}$ & $(6.1 \pm 1.8)^{\mathrm{ab}}$ & $\mathrm{AA}-\mathrm{A}$ \\
\hline 2.0 & $(5.1 \pm 1.1)^{c}$ & $(0.34 \pm 0.1)^{\mathrm{a}}$ & $(0.79 \pm 0.1)^{\mathrm{ab}}$ & $(7.1 \pm 2.6)^{\mathrm{bc}}$ & $\mathrm{AA}-\mathrm{A}$ \\
\hline 3.0 & $(7.9 \pm 1.2)^{\mathrm{d}}$ & $(0.30 \pm 0.1)^{\mathrm{ab}}$ & $(0.78 \pm 0.0)^{\mathrm{a}}$ & $(8.2 \pm 2.8)^{c}$ & $\mathrm{AA}-\mathrm{A}$ \\
\hline
\end{tabular}

Values are presented as mean \pm standard deviation of six repetitions per sampling $(N=3)$. Mean values in the same column with different letters are significantly $(\mathrm{p}<0.05)$ different 
Similar to the gel hardness data, fibre addition mostly increased the gel cohesiveness. However, no significant differences $(p \geq 0.05)$ were found between the treatments and the control, except at $2.0 \%$ fibre addition, which increased gel hardness by $21 \%$ when compared to the control.

Fibre addition also practically maintained or increased $(p \geq 0.05)$ gel springiness. Although $0.5 \%$ addition increased this parameter, it was statistically similar ( $\mathrm{p} \geq 0.05)$ to the control. Comparable results on hardness, springiness and cohesiveness behaviour were documented when ALMP (25\% amidation) was added to striped mullet (Mugil cephalus) restructured fish products (29). ALMP, being an anionic carbohydrate, can interact with the cationic groups of protein and to a lesser extent with hydrogen bonds, increasing the functional and mechanical properties of protein systems $(30,31)$. However, its addition can also affect the gelling process, depending on concentration and raw matter (32). Overall, the TPA results showed that ALMP addition benefitted the gelation characteristics of jumbo squid muscle proteins by increasing the measured parameters.

WBSF measures the maximum force encountered by the blade cutting action on the sample (19), mimicking the bite. In the present study, WBSF values tended to increase as fibre was added ( $\mathrm{p} \geq 0.05)$. Although $0.5 \%$ fibre addition reduced this value, the decrease was not significantly $(\mathrm{p} \geq 0.05)$ different to the control. At the highest amount of added fibre $(3.0 \%)$, this parameter increased by $36 \%$ $(p<0.05)$. Consequently. fibre addition increased the WBSF, in concurrence with the gel hardness values. Finally, the ALMP positively influenced the jumbo squid muscle gel characteristics, based on the folding test, showing gels with A-B and A-AA scores when $0.5-1.0 \%$ and 1.5-3.0 \% fibre were added, respectively. The texture results indicate that adding ALMP to jumbo squid muscle sol-gel promotes protein-ALMP interactions, increasing the gel mechanical characteristics. Although the addition of ALMP at any mass fraction improved jumbo squid muscle protein gel functionality, further research is required to confirm which fibre mass fraction is the most adequate, in terms of functionality and cost benefit of a gel-type product.

\section{Effect of ALMP on WHC of gels}

One characteristic of jumbo squid gels, besides their soft texture, is their poor WHC (6), showing syneresis during their handling. Besides carboxyl and amino groups, ALMP is relatively hydrophilic, possessing many hydroxyl groups. This interaction with water is the main reason these compounds are extensively used in the food industry (33). Fig. 1 shows the WHC of the jumbo squid gels with various ALMP mass fractions added. Fibre addition $(0.5 \%)$ increased $(\mathrm{p}<0.05)$ the capacity of gels to hold water $(18.5 \%$, from $(75.5 \pm 3.1)$ to $(89.5 \pm 1.8) \%$, control vs. $0.5 \%$ ALMP, respectively). Further addition (up to 2.0 $\%)$ maintained $(\mathrm{p} \geq 0.05)$ a similar water retention $((89.0 \pm 3.1),(87.9 \pm 2.4)$ and $(87.7 \pm 4.5) \%$ in samples with 1.0 , 1.5 and $2.0 \%$ ALMP, respectively). However, maximum water retention $((94.7 \pm 1.7) \%)$ was observed when $3.0 \%$ fibre was added, increasing the WHC by $25.5 \%$, com-

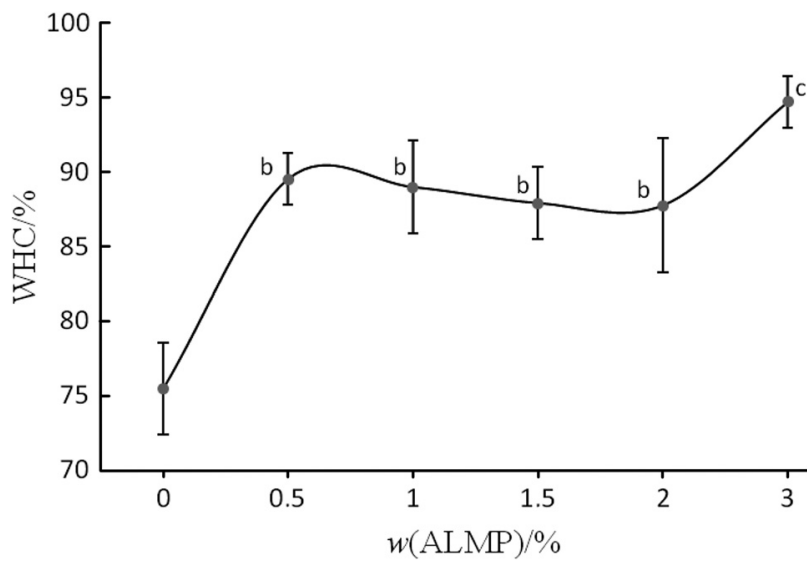

Fig. 1. Water holding capacity (WHC) of jumbo squid mantle muscle gels formulated with various mass fractions of amidated low-methoxyl pectin (ALMP). Points with different letters are significantly $(\mathrm{p}<0.05)$ different

pared to the control. These results suggest that a high level of carbohydrate-water interaction occurred in the samples, without affecting gel structure formation. Similar results were observed by Uresti et al. (30) and Rodríguez et al. (34), when they added ALMP of similar characteristics (27-33\% degree of esterification) to restructured fish products.

\section{Colour attributes}

Acceptance of a new product relies mainly on its colour, being the consumer's first perception. At 2.0 and 3.0 $\%$ addition, ALMP affected $(\mathrm{p}<0.05)$ the lightness $\left(L^{*}\right)$ of gels (Fig. 2), reducing this value from 86.0 (control) to 84.5 (1.7\% reduction) and 81.6 (5.1\% reduction), respectively. This is a significant change given that the human eye can detect a difference of a unit (35). Although small differences $(\mathrm{p}<0.05)$ were detected in the $a^{*}$ and $b^{*}$ parameters with the fibre addition, all treatments rendered very pale samples when these values $\left(L^{*}, a^{*}\right.$ and $\left.b^{*}\right)$ were set in the tridimensional colour solid (36). However, the whiteness index, and $L^{*}, a^{*}$ and $b^{*}$ integrating parameters were used to observe changes (Fig. 2) due to fibre addition. According to the $L^{*}$ values, differences $(\mathrm{p}<0.05)$ were observed only when 2.0 and $3.0 \%$ ALMP were added. The original fibre was yellow, thus, the observed changes were associated with the increasing concentration of fibre used, reducing the gel $L^{*}$ value and whiteness index, and increasing the $b^{*}$ parameter (more yellow) (Fig. 2).

\section{Thermal behaviour of ALMP-squid protein complexes}

Heat-set gelation of muscle proteins requires irreversible denaturation. This endothermic transition can be detected by differential scanning calorimetry (DSC). Generally, when a hydrocolloid is mixed with protein, it affects its thermal behaviour $(37,38)$. Thus, DSC was used to elucidate the ALMP effect on jumbo squid protein thermal behaviour. In the present study, the control (sol-gel without added fibre) and all treatments showed two endothermic peaks (Table 2), at around 46 and $71^{\circ} \mathrm{C}$, corresponding to myosin and actin, respectively (39). Fibre addition did not change $(\mathrm{p} \geq 0.05)$ the $t_{\text {onset }}$ of either of the 

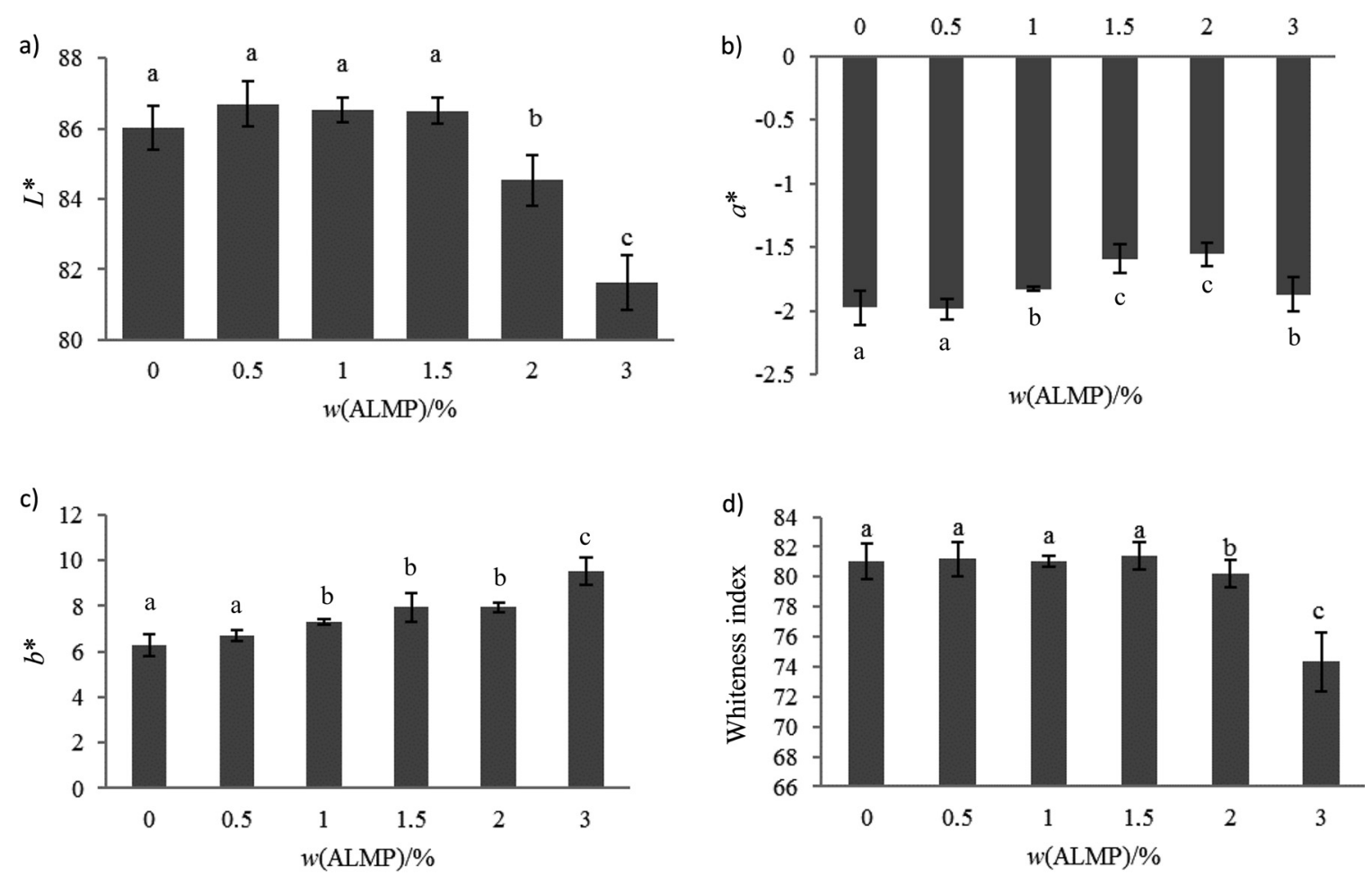

Fig. 2. Tristimulus colourimetry and whiteness index of jumbo squid mantle muscle gels formulated with various mass fractions of amidated low-methoxyl pectin (ALMP). Bars with different letters are significantly $(\mathrm{p}<0.05)$ different. Changes in: a) $L^{*}($ lightness), b) $a^{*}$ (redness/greenness), c) $b^{*}$ (yellowness/blueness), and d) whiteness index

Table 2. Calorimetric behaviour of jumbo squid mantle muscle gels formulated with various mass fractions of amidated low-methoxyl pectin (ALMP)

\begin{tabular}{|c|c|c|c|c|c|c|}
\hline \multirow{2}{*}{$w(\mathrm{ALMP}) / \%$} & \multicolumn{3}{|c|}{ Endotherm peak 1} & \multicolumn{3}{|c|}{ Endotherm peak 2} \\
\hline & $t_{\text {onset }} /{ }^{\circ} \mathrm{C}$ & $t_{\max } /{ }^{\circ} \mathrm{C}$ & $\Delta H /(\mathrm{J} / \mathrm{g})$ & $t_{\text {onset }} /{ }^{\circ} \mathrm{C}$ & $t_{\max } /{ }^{\circ} \mathrm{C}$ & $\Delta H /(\mathrm{J} / \mathrm{g})$ \\
\hline 0.0 & $41.6 \pm 1.2$ & $(46.1 \pm 0.5)^{\mathrm{b}}$ & $0.24 \pm 0.01$ & $68.4 \pm 1.2$ & $(71.0 \pm 1.0)^{\mathrm{b}}$ & $(0.11 \pm 0.03)^{\mathrm{a}}$ \\
\hline 0.5 & $41.8 \pm 1.4$ & $(46.1 \pm 0.7)^{b}$ & $0.25 \pm 0.03$ & $69.1 \pm 1.2$ & $(72.2 \pm 0.8)^{\mathrm{ab}}$ & $(0.17 \pm 0.04)^{\mathrm{ab}}$ \\
\hline 1.0 & $42.1 \pm 1.2$ & $(45.7 \pm 0.8)^{\mathrm{b}}$ & $0.21 \pm 0.03$ & $68.8 \pm 1.8$ & $(73.1 \pm 0.6)^{a}$ & $(0.15 \pm 0.04)^{\mathrm{ab}}$ \\
\hline 1.5 & $41.8 \pm 1.5$ & $(46.2 \pm 0.7)^{\mathrm{ab}}$ & $0.23 \pm 0.04$ & $68.4 \pm 0.9$ & $(72.3 \pm 0.6)^{\mathrm{ab}}$ & $(0.14 \pm 0.02)^{\mathrm{ab}}$ \\
\hline 2.0 & $41.9 \pm 0.6$ & $(46.8 \pm 0.8)^{\mathrm{ab}}$ & $0.24 \pm 0.02$ & $68.3 \pm 1.2$ & $(72.3 \pm 0.7)^{\mathrm{ab}}$ & $(0.19 \pm 0.05)^{\mathrm{b}}$ \\
\hline 3.0 & $41.6 \pm 1.6$ & $(47.4 \pm 0.4)^{\mathrm{a}}$ & $0.25 \pm 0.03$ & $68.3 \pm 1.0$ & $(72.6 \pm 0.4)^{\mathrm{ab}}$ & $(0.19 \pm 0.03)^{\mathrm{b}}$ \\
\hline
\end{tabular}

Values are the mean \pm standard deviation of six repetitions per sampling $(N=3)$. Mean values in the same column with different letters are significantly $(\mathrm{p}<0.05)$ different. $t_{\text {onset }}=$ onset temperature, $t_{\max }=$ temperature of maximum transition, $\Delta H=e n t h a l p y$ of transition. The endothermic peaks 1 and 2 represent the endothermic transitions of myosin and actin denaturation, respectively

endotherms, however, $t_{\max }$ of both endotherms increased $(\mathrm{p}<0.05)$ with higher temperatures and increasing fibre addition (i.e. by $1.3{ }^{\circ} \mathrm{C}$ at $3.0 \%$ fibre and $2.1{ }^{\circ} \mathrm{C}$ at $1.0 \%$ fibre of endotherms 1 and 2, respectively). On the contrary, a significant change $(\mathrm{p}<0.05)$ in net heat energy $(\Delta H)$ during thermal protein denaturation was observed only of endotherm 2 (actin), requiring more energy for denaturation as fibre was added. The shift in jumbo squid protein thermal behaviour might be ascribed to the rupture of hydrogen bonds (40), formed by a protein-carbohydrate interaction because this type of fibre is a high-molecular-mass complex polysaccharide, with considerable number of hydroxyl (-OH) groups (41).

\section{Electrophoretic profile}

Fig. 3 shows the electropherogram of the jumbo squid mantle muscle gels with various mass fractions of added ALMP. The main myofibrillar proteins found were myosin heavy chain, heavy meromyosin, paramyosin (the characteristic protein only found in invertebrates) and actin. In the present study, gel functionality could be improved by: (i) the presence of protein-protein covalent crosslinking, promoted by intrinsic muscle transglutaminase $(42,43)$, (ii) by the promotion of protein-carbohydrate noncovalent bonds or (iii) by a mixture of both. The electrophoretic pattern confirmed that the ALMP-induced changes in gelation and calorimetry were not a result of 


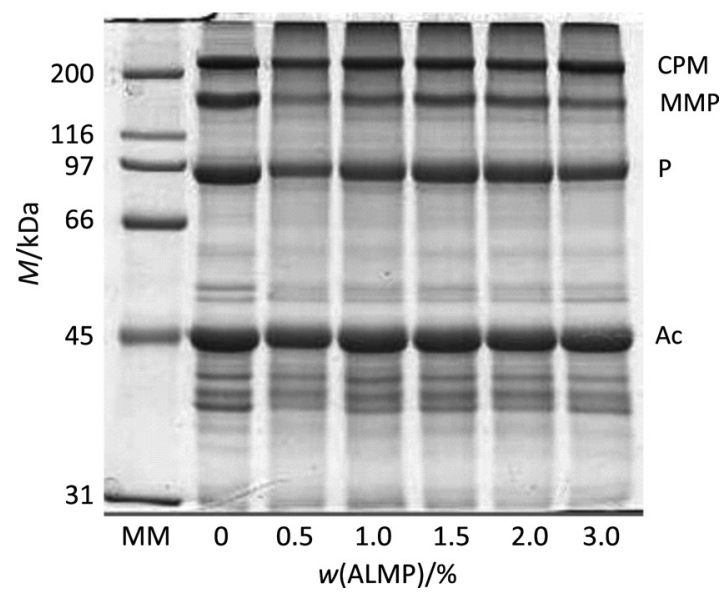

Fig. 3. Electropherogram of jumbo squid mantle muscle gels formulated with various mass fractions of amidated low-methoxyl pectin (ALMP). MM=broad-range molecular mass protein standard, $\mathrm{MHC}=$ myosin heavy chain, HMM=heavy meromyosin, $\mathrm{P}=$ paramyosin, $\mathrm{A}=$ actin

covalent interactions between fibre and/or proteins because no new high-molecular-mass bands appeared on the gel.

\section{Conclusions}

The present study demonstrated that amidated low-methoxyl pectin (ALMP; 0.5-3.0 \%) is an excellent ingredient to improve jumbo squid mantle muscle protein functionality, increasing texture and water retention characteristics of the produced gels. However, further research is needed to confirm which fibre mass fraction is most adequate in terms of functionality and cost benefit for a gel-type product.

\section{Acknowledgements}

The authors wish to thank M. C. Maria Elena Lugo Sanchez for all the unconditional support shown during the study.

\section{References}

1. Márquez-Ríos E, Morán-Palacio EF, Lugo-Sánchez ME, Ocano-Higuera VM, Pacheco-Aguilar R. Postmortem biochemical behavior of giant squid (Dosidicus gigas) mantle muscle stored in ice and its relation with quality parameters. J Food Sci. 2007;72:356-62.

https://doi.org/10.1111/j.1750-3841.2007.00468.x

2. Félix-Armenta A, Ramirez-Suarez JC, Pacheco-Aguilar R, Díaz-Cinco ME, Cumplido-Barbeitia G, Carvallo-Ruiz G. Jumbo squid (Dosidicus gigas) mantle muscle gelled-emulsified type product: formulation, processing and physicochemical characteristics. Int J Food Sci Tech. 2009;44:1517-24. https://doi.org/10.1111/j.1365-2621.2007.01709.x

3. Dihort-García G, Tolano-Villaverde IJ, Ezquerra-Brauer JM, Ocaño-Higuera VM, Ramírez de León JA, Torres-Arreola W, Marquez-Rios E. Effects of $\mathrm{pH}$ and sodium chloride on the gelling properties of a protein concentrate obtained from jumbo squid mantle (Dosidicus gigas). Int J Food Prop. 2016; 19:314-25.

https://doi.org/10.1080/10942912.2015.1021930
4. Sánchez-Alonso I, Careche M, Borderías AJ. Method for producing a functional protein concentrate from giant squid (Dosidicus gigas) muscle. Food Chem. 2007;100:48-54. https://doi.org/10.1016/j.foodchem.2005.09.008

5. Pérez-Mateos M, Montero P, Gómez-Guillén CM. Addition of microbial transglutaminase and protease inhibitors to improve gel properties of frozen squid muscle. Eur Food Res Technol. 2002;214:377-81.

https://doi.org/10.1007/s00217-001-0466-x

6. Ramirez-Suarez JC, Ibarra-León LR, Pacheco-Aguilar R, Lugo-Sánchez ME, García-Sánchez G, Carvallo-Ruiz G. Physicochemical and functional changes in jumbo squid (Dosidicus gigas) mantle muscle during ice storage. Food Chem. 2008;111:586-91.

https://doi.org/10.1016/j.foodchem.2008.04.024

7. Borderías AJ, Sánchez-Alonso I, Pérez-Mateos M. New applications of fibres in foods: addition to fishery products. Trends Food Sci Technol. 2005;16:458-65. https://doi.org/10.1016/j.tifs.2005.03.011

8. Troy DJ, Desmond EM, Buckley DJ. Eating quality of low-fat beef burgers containing fat-replacing functional blends. J Sci Food Agric. 1999;79:507-16.

https://doi.org/10.1002/(SICI)1097-0010(19990315)79:4<507: :AID-JSFA209>3.0.CO;2-6

9. Cardoso C, Mendes R, Vaz-Pires P, Nunes ML. Effect of dietary fibre and MTGase on the quality of mackerel surimi gels. J Sci Food Agric. 2009;89:1648-58. https://doi.org/10.1002/jsfa.3636

10. Elleuch M, Bedigian D, Roiseux O, Besbes S, Blecker C, Attia $\mathrm{H}$. Dietary fibre and fibre-rich by-products of food processing: characterisation, technological functionality and commercial applications: a review. Food Chem. 2011;124:411-21. https://doi.org/10.1016/j.foodchem.2010.06.077

11. Anderson JW, Baird P, Davis Jr RH, Ferreri S, Knudtson M, Koraym A, et al. Health benefits of dietary fiber. Nutr Rev. 2009;67:188-205. https://doi.org/10.1111/j.1753-4887.2009.00189.x

12. Savary BJ, Hotchkiss AT, Fishman ML, Cameron RG, Shatters RG. Development of a valencia orange pectin methylesterase for generating novel pectin products. In: Voragen F, Schols H, Visser R, editors. Advances in pectin and pectinase research. Dordrecht, The Netherlands: Springer Science+Bussiness Media; 2003. pp. 345-61. https://doi.org/10.1007/978-94-017-0331-4_26

13. Vincken JP, Schols HA, Oomen RJFJ, McCann MC, Ulvskov P, Voragen AGJ, Visser RGF. If homogalacturonan were a side chain of rhamnogalacturonan I. Implications for cell wall architecture. Plant Physiol. 2003;132:1781-9. https://doi.org/10.1104/pp.103.022350

14. AOAC Official Method 950.46. Forced air oven drying. Rockville, MD, USA: AOAC International; 2000.

15. AOAC Official Method 984.13. Protein (crude) in animal feed and pet food. Copper catalyst Kjeldahl method. Rockville, MD, USA: AOAC International; 2000.

16. AOAC Official Method 960.39. Fat or ether extract in meat. Rockville, MD, USA: AOAC International; 2000.

17. AOAC Official Method 938.08. Ash of seafood. Rockville, MD, USA: AOAC International; 2000.

18. Cortés-Ruiz JA, Pacheco-Aguilar R, Lugo-Sánchez ME, Carvallo-Ruiz MG, García-Sánchez G. Production and functional evaluation of a protein concentrate from giant squid (Dosidicus gigas) by acid dissolution and isoelectric precipitation. Food Chem. 2008;110:486-92.

https://doi.org/10.1016/j.foodchem.2008.02.030

19. Bourne MC. Food texture and viscosity: concept and measurement. New York, NY, USA: Academic Press; 2002. https://doi.org/10.1016/6978-0-12-119080-4.x5001-1 
20. Zhang M, Mittal GS. Measuring tenderness of meat products by Warner Bratzler shear press. J Food Process Preserv. 1993; 17:351-67. https://doi.org/10.1111/j.1745-4549.1993.tb00737.x

21. Tanikawa E, Motohiro T, Akiba M. Marine products in Japan. Tokyo, Japan: Koseisha Koseikaku Co. Ltd.; 1985.

22. Jiang ST, Ho ML, Lee TC. Optimization of the freezing conditions on mackerel and amberfish for manufacturing minced fish. J Food Sci. 1985;50:727-32. https://doi.org/10.1111/j.1365-2621.1985.tb13783.x

23. Lanier TC. Measurement of surimi composition and functional properties. In: Lanier TC, Lee CM, editors. Surimi technology. New York, NY, USA: Marcel Dekker, Inc.; 1992. pp. 123-63.

24. Pyris $^{\mathrm{TM}}$, v.4.02, PerkinElmer, Inc., Waltham, MA, USA; 2001. Available from: http://www.perkinelmer.com/.

25. Laemmli UK. Cleavage of structural proteins during the assembly of the head of bacteriophage T4. Nature. 1970;227: $680-5$. https://doi.org/10.1038/227680a0

26. Wang B, Xiong YL. Functional stability of antioxidant-washed, cryoprotectant-treated beef heart surimi during frozen storage. J Food Sci. 1998;63:293-8. https://doi.org/10.1111/j.1365-2621.1998.tb15729.x

27. NCSS 97, NCSS, LLC, Kaysville, UT, USA; 1997. Available from: https://www.ncss.com/.

28. Ezquerra-Brauer JM, Haard NF, Ramírez-Olivas R, OlivasBurrola H, Velazquez-Sánchez CJ. Influence of harvest season on the proteolytic activity of hepatopancreas and mantle tissues from jumbo squid (Dosidicus gigas). J Food Biochem. 2002;26:459-75. https://doi.org/10.1111/j.1745-4514.2002.tb00766.x

29. Ramírez JA, Rodríguez NR, Uresti RM, Velazquez G, Vázquez M. Fiber-rich functional fish food from striped mullet (Mugil cephalus) using amidated low methoxyl pectin. Food Hydrocolloid. 2007;21:527-36. https://doi.org/10.1016/j.foodhyd.2006.06.002

30. Uresti RM, López-Arias N, González-Cabriales JJ, Ramírez JA, Vázquez M. Use of amidated low methoxyl pectin to produce fish restructured products. Food Hydrocolloid. 2003;17: $171-6$. https://doi.org/10.1016/S0268-005X(02)00049-8

31. Chin KB, Go MY, Xiong YL. Konjac flour improved textural and water retention properties of transglutaminase-mediated, heat-induced porcine myofibrillar protein gel: effect of salt level and transglutaminase incubation. Meat Sci. 2009; 81:565-72. https://doi.org/10.1016/j.meatsci.2008.10.012

32. Ramírez JA, Uresti RM, Velazquez G, Vázquez M. Food hydrocolloids as additives to improve the mechanical and functional properties of fish products: a review. Food Hydrocolloid. 2011;25:1842-52. https://doi.org/10.1016/j.foodhyd.2011.05.009

33. Li JM, Nie SP. The functional and nutritional aspects of hydrocolloids in foods. Food Hydrocolloid. 2016;53:46-61. https://doi.org/10.1016/j.foodhyd.2015.01.035

34. Rodríguez NR, Uresti RM, Velazquez G, Vázquez M, Ramírez JA. Effects of amidated low methoxyl pectin on healthy restructured fish food from Mexican flounder (Cyclopsetta chittendeni). J Food Process Eng. 2008;31:229-46. https://doi.org/10.1111/j.1745-4530.2007.00149.x

35. Mesbahi G, Jamalian J, Farahnaky A. A comparative study on functional properties of beet and citrus pectins in food systems. Food Hydrocolloid. 2005;19:731-8. https://doi.org/10.1016/j.foodhyd.2004.08.002

36. Precise color communication. Konica Minolta, Inc, Tokio, Japan; 2011. Available from:

https:/www.konicaminolta.com/instruments/knowledge/ color/part1/07.html.

37. Tolano-Villaverde IJ, Ezquerra-Brauer JM, Ocano-Higuera VM, Torres-Arreola W, Ramirez-Wong B, Herrera-Urbina R, Marquez-Rios E. Effect of $\mathrm{pH}$ and chitosan concentration on gelation of protein concentrate from giant squid mantle (Dosidicus gigas). Int J Food Sci Technol. 2016;51:1360-8. https://doi.org/10.1111/ijfs.13095

38. Pérez-Mateos M, Hurtado JL, Montero P, Fernández-Martín F. Interactions of $\kappa$-carrageenan plus other hydrocolloids in fish myosystem gels. J Food Sci. 2001;66:838-43. https://doi.org/10.1111/j.1365-2621.2001.tb15183.x

39. Hong GP, Xiong YL. Microbial transglutaminase-induced structural and rheological changes of cationic and anionic myofibrillar proteins. Meat Sci. 2012;91:36-42. https://doi.org/10.1016/j.meatsci.2011.12.002

40. Privalov PL, Khechinashvili NN. A thermodynamic approach to the problem of stabilization of globular protein structure: a calorimetric study. J Mol Biol. 1974;86:665-84. https://doi.org/10.1016/0022-2836(74)90188-0

41. Chen J, Liu W, Liu CM, Li T, Liang RH, Luo SJ. Pectin modifications: a review. Crit Rev Food Sci Nutr. 2015;55:1684-98. https://doi.org/10.1080/10408398.2012.718722

42. Nozawa H, Cho SY, Seki N. Purification and characterization of transglutaminase from squid gill. Fisheries Sci. 2001;67: 912-9. https://doi.org/10.1046/j.1444-2906.2001.00341.x

43. Nozawa H, Mamegoshi S, Seki N. Partial purification and characterization of six transglutaminases from ordinary muscles of various fishes and marine invertebrates. Comp Biochem Physiol Biochem Mol Biol 1997;118:313-7. https://doi.org/10.1016/S0305-0491(97)00062-X 